\author{
A. Serkov ${ }^{1}$, V. Breslavets ${ }^{1}$, M. Tolkachov ${ }^{1}$, G. Churyumov ${ }^{2}$, Issam Saad ${ }^{1}$ \\ ${ }^{1}$ National Technical University "Kharkiv Polytechnic Institute", Kharkiv, Ukraine \\ ${ }^{2}$ Kharkiv National University of Radio Electronics, Kharkiv, Ukraine
}

\title{
NOISE-LIKE SIGNALS IN WIRELESS INFORMATION TRANSMISSION SYSTEMS
}

\begin{abstract}
The subject matter is analysis and evaluation of efficiency of noise-like signals in wireless information transmission systems. The aim is quality of service improvement for mobile subscribers, due to communication channel multiplexing using complex signal-code structures. The objective is development of a systemic view of the technology of information transmission using ultra-short pulse signals focusing on main phenomena that arise at different stages of signal transmission in a wireless information transmission system. The methods use dare sequential analysis, simulation modeling and digital signal coding. The following results have been obtained. An antenna design featuring an expanding slit has been proposed for effective emission and reception of noise-like signals. A method for controlling radiation pattern of such antenna array has been developed. Gaussian Monocycle coding of information with time position-pulse modulation has been justified to be used as a noise-like signal. It has been shown that for the organization of independent channels in one frequency band, it is practical to use a system of orthogonal codes, e.g. Walsh sequence. Due to accumulation of pulses of a useful information signal in the receiver correlator, significant increase in signal-to-noise ratio becomes possible, which enables information transmission over a wide frequency range well below the noise level. As a result, a systematic understanding of the technology of information transmission using ultra-short pulse signals in wireless information transmission systems is developed and a quantitative evaluation of the efficiency of the proposed technical solutions is provided. Conclusion. The use of noise-like signals in wireless information transmission systems provides for high data transmission rates with high interference immunity and tapping protection communication channel. The ability to operate with low emitted power and the high penetrability of noise-like signals through various obstacles, for example, walls, allow meeting the requirements for electromagnetic compatibility and ensuring stable communication in conditions of multipath propagation of radio waves. These circumstances form the basis for the development and implementation of information transfer technology using noise-like signals when designing office networks.
\end{abstract}

Keywords: noise-like signal; wireless information transmission system; time position-pulse modulation; orthogonal coding; electromagnetic compatibility.

\section{Introduction}

The first practical experiments in wireless information transmission, conducted by A.S. Popov and G. Marconi, showed the possibility of signal transmission at a distance of tens of kilometers. Information was carriedwith electromagnetic pulses that occur during a spark discharge. It should be noted that information is an ordered set of fixed symbols (pulses) of arbitrary nature $[1,2]$.

The development of information transfer technologies would have proceeded in the direction of improving and developing pulse information transfer systems but a mathematical apparatus of harmonic analysis, introduced at that time, laid a foundation of a communication theory based on sinusoidal functions, which gave a powerful impetus to the development of this realm. However, treating information systems in terms of harmonic oscillations gradually accumulated a set of problems, and that stimulated transition to noiselike (pulse) signals in wireless information transmission systems (WITS). H. Harmuth showed [3-5] that harmonic signals in WITS are a particular case of nonsinusoidal oscillations, and that Sequential Analysis Theory being applied here allows avoiding many of the problems that arise from usage of Harmonic Analysis methods [4].

Practical implementations of WITS devices have proved this theory adequate [5]. This approach was further developed by American scientists D. Ross, K. Robbins and L. Fullerton (Fig. 1). The latter has coined the term "pulse radio" and founded Time Domain Corp., which has successfully worked in this field since 1987.

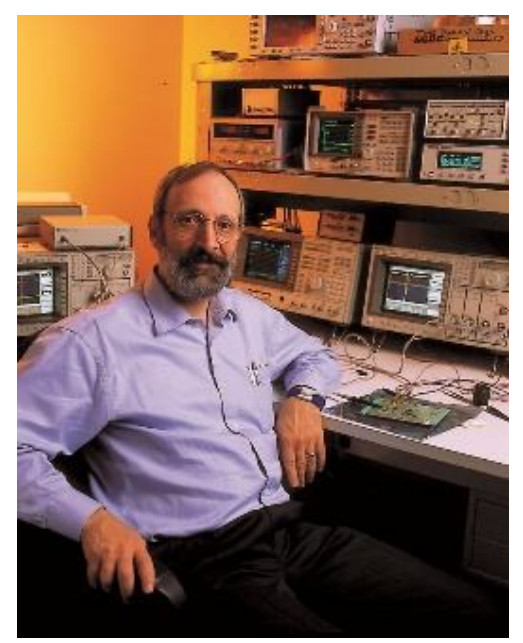

Fig. 1. Larry Fullerton

Wireless information transmission systems work with large streams of diverse information, providing a high-quality exchange of information among subscribers. However, further increase in the number of wireless devices typically connected to a WITS imposes stricter requirements upon the information transmission medium, which leads to communication channel multiplexing using complex signal-code patterns. Depending on the correlation properties of coded information signals, a code division of the channels is 
used, and each channel is assigned a specific waveform serving as a distinctive feature of the channel.

The use of noise-like signals (NLS) improves the information transmission speed as well as secrecy and reliability of mobile communication channels. Moreover, the use of NLS in wireless communication systems provides for simultaneous high-quality joint operation of a large number of devices. The implementation of such joint operation is currently an actual and complex task.

\section{The analysis of the problem and formulation of the task}

According to the definition provided by L. Astanin [6], in noise-like signals, spectral width is commensurable with central frequency. In broadband transmission, relatively narrowband information signals with an effectively transmitted spectral width $\Delta f$ are deliberately converted to wideband signals with effectively transmitted spectral width $\Delta F$, preserving the level of total signal energy $E$. Spectral energy density of the channel signal is deliberately reduced $\Delta F / \Delta f$ times, which results in value of $\Delta E / \Delta F$, while the channel signal base rises $\Delta F / \Delta f$ times. The basis of the ultrashort pulse (i.e. NLS) is equal to a product of the signal duration by its spectrum width:

$$
B=\Delta t \cdot \Delta F \approx 1,
$$

where $\Delta t$ is the pulse duration, and $\Delta F$ is the pulse power spectrum width.

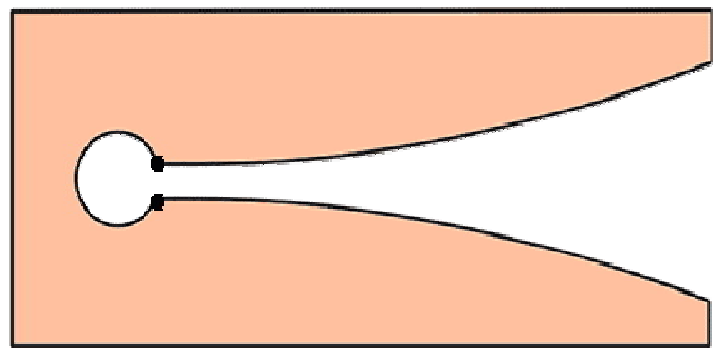

Thus, direct expansion of the frequency spectrum is the simplest and the most convenient method to expand the signal base. E.g. using a Gaussian monocycle with a duration $\Delta t$ ranging from $2.0 \mathrm{~ns}$ to $0.1 \mathrm{~ns}$ as a coding pulse results in the bandwidth of power spectrum from $500 \mathrm{MHz}$ to $10 \mathrm{GHz}$, respectively; while the signal spectrum occupies the entire frequency band from 0 to $\Delta F \approx 1 / \Delta t$. To encode a symbol of information not a single ultra-short pulse but a sequence of them is used, and the signal base increases in proportion to the number of pulses.

Radiating a broadband signal's electromagnetic wave to free space imposes restrictions on the design of antenna devices used. For organization of WITS that utilize noise-like signals, the characteristics of the generators, radiators and receivers have to be optimized for the nature of the signals.

\section{Task solution}

Antenna e. The analysis [7] of the design of antenna array elements for emission of ultra-short pulses reveals that the best results are obtained with Tapered Slot Antenna (TSA) also known as Vivaldi Antenna, which is an antenna with an expanding slit. A TSA is fed with a signal from a short pulse generator [7]. These antennae are of complex shape, so we used a 3D electrodynamic simulation software package to study their characteristics. TSA size/shape optimization performed with the software results in a variety of shapes and proportions, depending on the specific task (Fig. 2).

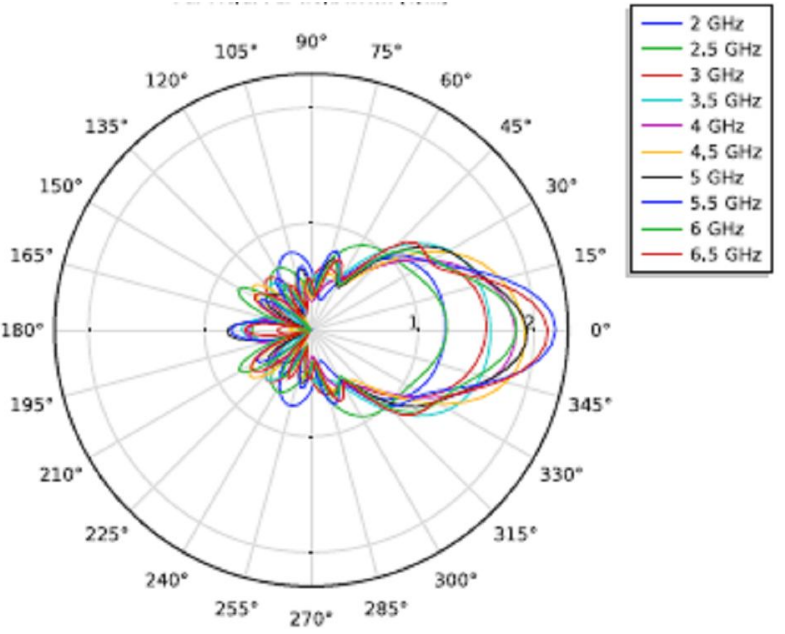

Fig. 2. The design of TSA and radiation patterns of the antenna for frequencies of $2.0-6.5 \mathrm{GHz}$

Antenna width limits the lower radiation frequency, as in the case of a dipole, while antenna length determines the gain in the middle and at the upper edge of the band, like with log-periodic or horn antennae. The shape of the open slit determines the frequency band as with log-periodic antennae. The shape of the slit can be different, but the widest band is obtained with exponential (for example, $\mathrm{e}^{0044 x}$ ) increase in the slit width. The dimensions and the shape of the hole affect the matching at the bottom of the frequency band. A TSA is usually produced with conductors printed on fiberglass. The influence of the dielectric somewhat lowers the frequency and the input resistance, but the latter remains well above 50 Ohms: $140-160 \mathrm{Ohm}$, depending on the fiberglass thickness. A distinctive feature of phased antenna arrays using TSAs as their basic element is the significant expansion of the frequency band of electromagnetic radiation, which is important for the usage of the arrays in wideband WITS. In this case, we also getexcess values of frequency and gain. The energy radiation pattern of such pulsed antenna array is characterized by a narrow main beam and practically no side lobes.

Thus, considering their bandwidth, gain and beam characteristics, antenna arrays consisting of TSA elements are the most suitable for usage in WITS. 
Besides, as it was shown in [8], the direction of the maximum of the radiation diagram can be changed through changing the shape of the pulse current/voltage feeding the transmitting antenna (Fig. 3). The radiation diagram pattern control is based on the properties of pulse waveforms and utilizes changes in the energy spectrum of the signal depending on the receiving direction. This property can be used to control antenna radiation diagram pattern when aligning the maximum directions of transmitting and receiving antennae of a WITS. Using changes in the shape of the pulse wave, we can automate beam control.

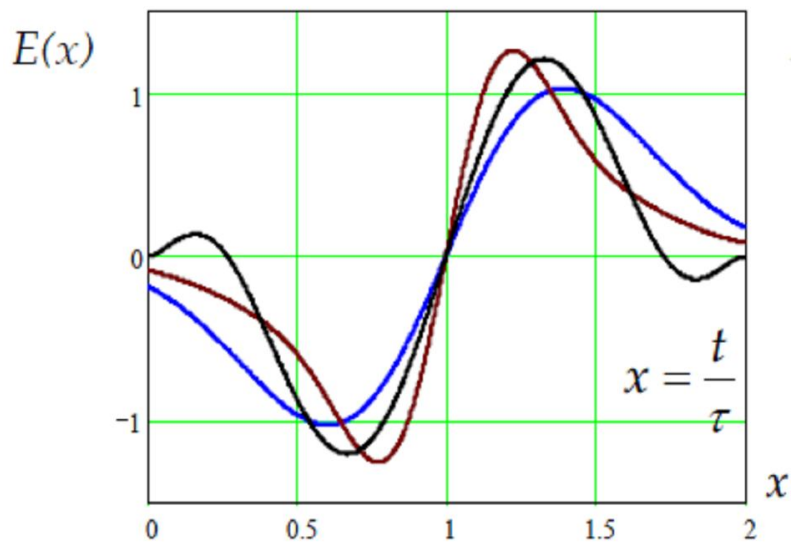

Fig. 3. Signal forms for changing the direction of radiation
Generation. One of the most important elements in implementation of a WITS basing on noise-like signals consists in powerful pulse keys. Their commutation front duration must be about 10-100 pswith a megahertz repetition rate and a very high stability during about 10 ps. In this case, the commutated voltage is measured in hundreds and thousands volts.

Since radiation of an antenna electromagnetic wave to free space is formed at the moment of a sharp drop in the voltage pulse front, it becomes necessary to generate pulses with the highest possible slew rate. High-speed circuit breaking switches can be constructed from drift step recovery diodes as it was first demonstrated at Ioffe Institute [9]. Such diodes can switch voltages up to $1800 \mathrm{~V}$. A pulse of such amplitude corresponds to current of $36 \mathrm{~A}$. Thus with such diodes, it is possible to form ultra-short voltage pulses with $2-4 \mathrm{~V} / \mathrm{ps}$ rising front rate. A typical pulse shape of an ultra-short voltage pulse generator (UVPG) is shown in Fig. 4 [7].

A family of electric pulse generators has been developed based on short pulse power keys proposed by the group of A. Kardo-Sysoev (see Table 1 for their technical characteristics).

It should also be noted that the developed generators have almost unlimited service life, which makes them an ideal basis for development of powerful ultra-wideband transmitters.

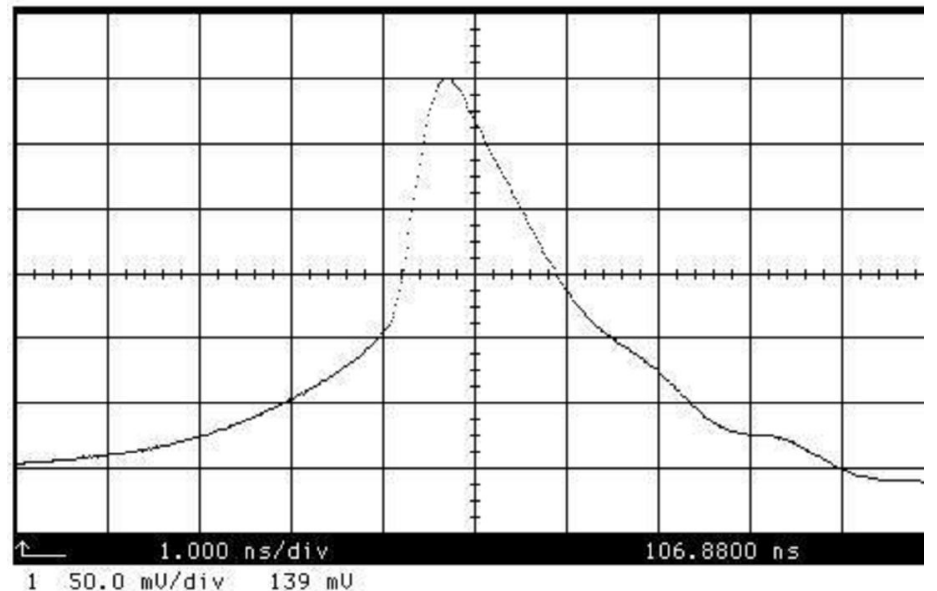

Fig. 4. Typical pulse shape of the UVPG generator

Particular properties of noise-like signal applications. Usually, noise-like signals have the form of idealized Gaussian Monocycles with radiation spectrum mainly in the range from 1 to $7 \mathrm{GHz}$. The pulse duration ranges from 200 picoseconds to a nanosecond, and the pulse repetition intervals range from 10 to $1000 \mathrm{~ns}$. An average pulse repetition period determines the information transmission rate. Therefore, at a pulse repetition period of $10 \mathrm{~ns}$ the maximum transmission rate is $100 \mathrm{Mbit} / \mathrm{s}$.

The need to increase the performance of WITS forces us to use complex signals that can significantly improve the quality of information transmission. Obtaining high information transfer rates can be possible with ultra-dense communication channel design using complex signal-code structures for information transfer. Such channels provide data transfer rates close to communication channel bandwidths.

However, a regular sequence of such pulses does not carry any information. Therefore, one information bit is encoded by a sequence of many pulses, e.g. 200 pulses per bit. Information is encoded using Pulse Position Modulation (PPM) when the information parameter of an information bit consist in time positions of the leading edges of the 200 pulses representing the bit.

The position of each of the coding pulses varies in time in respect to positions of periodic reference pulses. Forward displacement of the pulse relative to its nominal position in the sequence denotes ' 0 ', 
backward-' 1 '. The magnitude of the displacement should not exceed a quarter of the pulse duration. For example, in a sequence of pulses with $0.5 \mathrm{~ns}$ duration and $100 \mathrm{~ns}$ intermittent interval a pulse that came $100 \mathrm{ps}$ earlier denotes 'zero', and the one coming 100 ps later denotes 'one'.

Table 1. Generators of ultra-wideband pulses

\begin{tabular}{|l|c|c|c|c|}
\hline Model & Rise time, $\mathbf{n s .}$ & Pulse Width, ns. & Amplitude, $\mathbf{~}$ & Repetition Rate, MHz \\
\hline HFPG-1-0,5 & $<0,7$ & $<2$ & 500 & $2(3)$ \\
\hline HFPG-1-2,5 & $<0,7$ & $<2$ & 2500 & $(2)$ \\
\hline HFPG-1-5 & $<0,7$ & $<2$ & 5000 & $(0,5)$ \\
\hline HFPG-5-0,05 & $<0,14$ & $<0,3$ & 50 & $10(20)$ \\
\hline HFPG-7-0,15 & $<0,3$ & $<0,7$ & 150 & $10(20)$ \\
\hline HFPG-7-0,5 & $<0,3$ & $<0,7$ & 500 & 2 \\
\hline HFPG-7-1 & $<0,3$ & $<0,7$ & 1000 & 1 \\
\hline HFPG-4-0,5 & $<0,1$ & $<0,5$ & 500 & $(0,2)$ \\
\hline HFPG-4-1-10 & $<0,1$ & $<0,25$ & 1100 & 0,01 \\
\hline HFPG-4-1-50 & $<0,1$ & $<0,25$ & 1100 & 0,05 \\
\hline
\end{tabular}

For organization of several independent channels within a single frequency band with smoothing spectral characteristics and protection from interference, the position of each information bit is shifted by time proportional to a current value of some pseudo-random sequence. The shift time is one or two orders of magnitude higher than the offset at PPM modulation. Using a system of orthogonal codes to control time delays, e.g. Walsh Sequence, up to a thousand independent communication channels can be created within one band without using special algorithms for digital signal processing. Thus, all the channels occupy a single wide frequency range, and the signal spectrum is substantially smoothed out and becomes noise-like. Due to the broadband signal, its power is reduced, even below the white noise level - in case of very long base.

To select a signal that is intended for this receiver from the total mass of radio signals, a separate numerical code assigned to each user can be applied. All other signals would be regarded as noise.

AWITS receiver is a direct gain receiver and a correlator. Being synchronized with the transmitter and knowing the law of generation of the pseudo-random sequence of pulses in time, the receiver synchronously generates a sequence of reference pulses for the correlator. The correlator determines the coincidence of the reference and received pulses, setting the output to +1 , if the signal comese.g. $100 \mathrm{ps}$ before the end of the inter-pulse interval, -1 - if 100 ps after and $0-$ in all other cases. These values are accumulated in an integrator. As a result, narrowband interference from a continuous carrier transmitter or a signal from another pulse transmitter can impede correct receiving of individual pulses, not the information bit as a whole. The value accumulated at the correlator from random interference would be zero. This allows avoiding signal interference that may occur when organizing communication within buildings or on complex terrain. The reflected signal enters the correlator with a delay and the correlator interprets it as a random interference without affecting the direct signal anyhow. Estimation of noise tolerance can be done using the concept of processing gain. In spread spectrum systems, processing gain is defined as the ratio of channel bandwidth to information signal bandwidth. Thus, for spreadingspectrum systems using direct sequence method with channel bandwidth of $5 \mathrm{MHz}$ and information signal bandwidth of $10 \mathrm{kHz}$, the gain would be $27 \mathrm{~dB}$. For the same signal transmitted through a $2 \mathrm{GHz}$ bandwidth, the gain would be $53 \mathrm{~dB}$. So due to the high effective amplification of signals in noise-like systems, they can operate at very low average transmitter power $(50 \mu \mathrm{W}$ $2 \mathrm{~mW}$ ). Therefore, they do not interfere with existing radio engineering systems using the same frequency band.

Due to the broadband character of the signal, its attenuation in various media is insignificant. Short pulses easily pass through various obstacles, since signal suppression does not occur throughout the entire band. Due to different paths of propagation of radio waves (multipath propagation), interference of signals occurs, which creates a complex electromagnetic situation at the receiver site. A digitally coded signal comes in the form of several copies shifted in time. However, if the difference in the shift is greater than chip duration then the receiver synchronizes with the most powerful component of the received signal discarding the other.

Thus, the resistance to multipath propagation of the WITS signals is ensured.

\section{Analysis}

It should be noted that while average power of emitted pulses is relatively small, the magnitude of the electric component of the electromagnetic field reaches very high values. This increases the likelihood of a malfunction and possible failure of ambient radio electronic equipment. The studies of resistance of radio electronic equipment to the impact of ultra-short voltage pulses (UVP) performed by K. Sakharov's school [11- 
15] determined the maximum permissible levels of pulsed electromagnetic fields that guarantee uninterrupted operation of the equipment. These levels are different for different radioelectronic systems and depend also on the repetition rate of the pulses. E.g. the maximum allowable intensity of the electric component of an electromagnetic field generated by a UVP ranges from $2 \mathrm{kV} / \mathrm{m}$ for $1 \mathrm{MHz}$ repetition rate to $300 \mathrm{kV} / \mathrm{m}-$ for $1 \mathrm{KHz}$. The analysis and generalization of experimental results revealed that at a $10 \mathrm{MHz}$ repetition rate of UVP (100 ns repetition period) the intensity of the electric component of the electromagnetic field of the UVP would not exceed $300 \mathrm{~V} / \mathrm{m}$.

This limitation can be met in practice using a UVP generator out of the family of generators developed by A. Kardo-Sysoev's group [10]. HFPG-5-0,05 or HFPG$7-0,15$ models with $0.14-0.3 \mathrm{~ns}$ rise time, $0.3-0.7 \mathrm{~ns}$ pulse duration and 50-150 V amplitude, ensuring temporal stability of pulse positions in order of $10 \mathrm{ps}$ are the most suitable for the task.

\section{Conclusions}

The usage of noise-like signals in the WITS allows obtaining a number of advantages that cannot be achieved with traditional methods. It concerns, in particular, improving the quality of service for mobile communication, such as the increase in the number of subscribers served simultaneously. Communication channel bandwidth expansion and transition to ultrawideband channels leads to practically unlimited increase in the number of communication channels. Preallocating signals, their frequencies and modulation types to subscribers, we can implement inter-subscriber communication without mutual listening-in and interference.

The most important criterion characterizing the efficiency of wireless communication systems is the high potential unit density of data transmission. It is defined as the amount of achievable total data transfer rate per square meter of the working area and now this value is about $1 \mathrm{Mbit} / \mathrm{s} / \mathrm{m}^{2}$.

The use of short pulses prevents inter-signal distortion since the energy of the received pulse usually has time to die out completely until the next one arrives. This also reduces the level of distortion of information signals caused by its multipath propagation. Therefore, low power noise-like systems are able to transmit data inside buildings with complex architecture.

A characteristic feature inherent to communication systems based on noise-like signals is the low probability of either detection of a fact of temporary establishment of a communication channel or unauthorized access to the information transmitted through the channel. Moreover, in this case, mobile operators do not need to obtain additional band licenses and use already occupied radio frequency bands.

Simultaneous joint interference-free operation in the same frequency band for either traditional narrowband communication systems or communication systems with noise-like signals is possible because the level of the information signal does not exceed the noise level in the band of operation. At the same time, the reduction in the power and the level of electromagnetic field radiation makes it possible to ensure compliance with the requirements of electromagnetic compatibility at all stages of development and implementation of mobile communication systems.

\section{REFERENCES}

1. Serkov, A.A. and Logvinenko, N.F. (2009), "Development of Approaches to Creating the Theory of the Value of Information", Bulletin of NTU "KhPI". Themes. Vyp.: Informatics and Modelling, NTU "KhPI", Kharkiv, No. 2, pp. 18-24.

2. Shannon, K. (1963), Works on Information Theory and Cybernetics, Nauka, Moscow, $830 \mathrm{p}$.

3. Harmuth, H.F. (1969), Transmission of Information by Orthogonal Functions, Springer-Verlag, Berlin, Heidelberg, New York, $269 \mathrm{p}$.

4. Harmuth, H.F. (1980), Sequency Theory: Foundations and Applications, Academic Press, New York, 575 p.

5. Harmuth, H.F. (1981), Non sinusoidal Waves for Radar and Radio Communication, Academic Press, New York, London, Toronto, Sydney, San Francisco, 376 p.

6. Varganov, M.E., Zinoviev, Yu.S. and Astanin, L.Yu. (1985), Radioactive Characteristics of Aircraft, Radio and Communication, Moscow, 230 p.

7. Kochetov, A.V. (2013), "Element of the antenna array for the emission of powerful ultrashort pulses", Collection of proceedings of the IV All-Russian scientific conference "Ultra-wideband signals in radar, communications and acoustics", pp. 211-215.

8. Shostko, I.S. (2011), "Methods of forming a directional pattern in ultra-wideband antenna arrays for wireless access points", Problems of telecommunications, No. 1 (3), pp. 52-61, available at : http://pt.journal.kh.ua (last accessed March 15, 2017).

9. Smirnov, A.A, Ivanov, B.V, Cardo-Sysoev, A.F. and Shevchenko, S.A. (2015), "Investigation of the process of formation of subnanosecond voltage drops by carbide-silicon drift diodes with a sharp recovery", NAUKOVODENIE, Vol. 7, No. 4, available at : http://naukovedenie.ru/PDF/141TVN415.pdf (last accessed March 15, 2017), DOI : 10.15862/141TVN415.

10. Shakhnovich, I.V. (2001), "Ultra-wideband Communication. Second Birth?", Electronics Science Technology Business, No. 4, pp. 8-15.

11. Sakharov, K.Yu. (2006), Emitters of ultrashort electromagnetic pulses and methods for measuring their parameters, Publishing house of MIEM, Moscow, $159 \mathrm{p}$.

12. Mikhailov, K.A., Sakharov, K.Yu. and Turkin, V.A. (2008), "Evaluation of the durability of on-board computers in conditions of ultrashort electromagnetic fields influence", EMC Technologies, No. 4, pp. 12-19.

13. Sakharov, K.Yu., Yankovsky, B.D. and Edlin, M.Yu. (2009), "Influence of ultrashort electromagnetic pulses on the execution of information function of digital devices with non-volatile memory", EMC Technologies, No. 3, pp. 47-54. 
14. Akbashev, B.B., Batonov, N.M., Sakharov, K.Yu. and Turkin, V.A. (2011), "Stability of video surveillance systems to the effect of powerful ultrashort electromagnetic pulses", EMC Technologies, No. 2 (37), pp. 24-29.

15. Akbashev, B.B., Batonov, N.M., Sakharov, K.Yu. and Turkin, V.A. (2011), "Experimental studies of the operation of devices of a standard integrated security system under the influence of ultra short electromagnetic fields", EMC Technologies, No. 2 (37), pp. 30-36.

Received (Надійшла) 11.06.2017

Accepted for publication (Прийнята до друку) 19.09.2017

\section{Шумоподібні сигнали у безпроводових системах передачі інформації}

\section{О.А. Серков, В.С.Бреславець, М.Ю. Толкачов, Г.І. Чурюмов, Іссам Саад}

Предметом вивчення $є$ процеси аналізу та оцінки ефективності використання шумоподібних сигналів в безпроводових системах передачі інформації. Мета - підвищення показників якості обслуговування абонентів мобільного зв'язку шляхом ущільнення каналів зв'язку за рахунок застосування складних сигнально-кодових конструкцій. Завдання: формування системного уявлення щодо технології передачі інформації надкороткими імпульсними сигналами із виділенням основних особливостей, які виникають на різних етапах проходження сигналів у безпроводній системі передачі інформації. Методами, що використовувались, є такі: секвентний аналіз, методи імітаційного моделювання та цифрового кодування сигналів. Отримані такі результати. Для ефективного випромінювання та прийому шумоподібних сигналів запропонована конструкція антени із щілиною, яка розширюється. Запропоновано метод керування діаграмою спрямованості цієї антенної решітки. Обгрунтовано використання у якості шумоподібного сигналу гаусівського моноциклу із кодуванням інформації за допомогою часової позиційно-імпульсної модуляції. Показано, що для організації незалежних каналів в одній смузі частот доцільно використовувати систему ортогональних кодів, наприклад, послідовність Уолша. Накопичені у кореляторі приймача імпульси корисного сигналу дають можливість суттєво підвищити співвідношення сигнал/ шум, забезпечуючи цим можливість передачі інформації у широкому частотному діапазоні значно нижче рівня шуму. В результаті сформовано системне уявлення про технологію передачі інформації надкороткими імпульсами у безпроводових системах передачі інформації. Також проведені кількісні та якісні оцінки ефективності запропонованих технічних рішень. Висновки. Використання шумоподібних сигналів у безпроводових системах передачі інформації дозволяє забезпечити великі швидкості передачі інформації 3 одночасною високою завадозахищеністю та захистом його від перехоплення. Можливість працювати із малою потужністю випромінювання та висока проникливість шумоподібних сигналів крізь будь-які перешкоди, наприклад, стіни, дозволяють виконати вимоги щодо електромагнітної сумісності та забезпечити стійкий зв'язок в умовах багатопроміневого розповсюдження радіохвиль. Ці обставини створюють підгрунтя для розвитку та впровадження технології передачі інформації із застосуванням шумоподібних сигналів при створенні офісних мереж.

Ключові слова: шумоподібний сигнал; безпроводова система передачі інформації; часова позиційно-імпульсна модуляція; ортогональне кодування; електромагнітна сумісність.

\section{Шумоподобные сигналы в беспроводных системах передачи информации}

А.А. Серков, В.С. Бреславец, М.Ю. Толкачов, Г.И. Чурюмов, Иссам М. Саад

Предметом изучения являются процессы анализа и оценки эффективности использования шумоподобных сигналов в беспроводных системах передачи информации. Цель - повышения показателей качества обслуживания абонентов мобильной связи путем уплотнения каналов связи за счет применения сложных сигнально-кодовых конструкций. Задача: формирование системного представления о технологии передачи информации сверхкороткими импульсными сигналами с выделением основных особенностей, возникающих на различных этапах прохождения сигналов в беспроводной системе передачи информации. Используемыми методами являются: секвентный анализ, методы имитационного моделирования и цифрового кодирования сигналов. Получены следующие результаты. Для эффективного излучения и приема шумоподобных сигналов предложена конструкция антенны с расширяющейся щелью. Предложен метод управления диаграммой направленности этой антенной решетки. Обосновано использование в качестве шумоподобного сигнала гауссовского моноцикла с кодированием информации посредством временной позиционно-импульсной модуляции. Показано, что для организации независимых каналов в одной полосе частот целесообразно применять систему ортогональных кодов, например, последовательность Уолша. Накопленные в корреляторе приемника импульсы полезного информационного сигнала дают возможность существенно повысить соотношение сигнал/шум, обеспечивая возможность передачи информации в широком частотном диапазоне значительно ниже уровня шума. В результате сформировано системное представление о технологии передачи информации сверхкороткими импульсными сигналами в беспроводных системах передачи информации и проведена количественные и качественные оценки эффективности предлагаемых технических решений. Выводы. Использование шумоподобных сигналов в беспроводных системах передачи информации позволяет обеспечить большие скорости передачи информации при высокой помехозащищенности канала связи и защиты его от перехвата. Возможность работы с малой излучаемой мощностью и высокая проникающая способность шумоподобных сигналов через различные препятствия, например, стены, позволяют выполнить требования по электромагнитной совместимости и обеспечить устойчивую связь в условиях многолучевого распространения радиоволн. Эти обстоятельства создают основу для развития и внедрения технологии передачи информации с использованием шумоподобных сигналов при создании офисных сетей.

Ключевые слова: шумоподобный сигнал; беспроводная система передачи информации; временная позиционноимпульсная модуляция; ортогональное кодирование; электромагнитная совместимость. 